\title{
Problemas de Menores no Âmbito Internacional e Direito de Comunicação Social
}

Prof. Antônio Chaves

Dois acontecimentos internacionais demonstram a crescente preocupação com relação ao problema dos menores sem família.

O primeiro foi a convocação de um Grupo de Peritos pelo Centro para o Desenvolvimento Social e Questōes Humanitárias da Organização das Nações Unidas, de 11 a 15.12 .1978 , em Genebra, a fim de preparar um projeto de declaração, solicitado pelo Conselho Econômico e Social, pela Resolução no 1925, de 06.05.1975, a respeito da adoção e favorecimento da colocação de crianças.

Apresentou ele "Conclusões e Recomendações" visando 6 itens relativos ao bem-estar geral da família e das crianças, 5 , ao favorecimento da colocação e 14 relativos à adoção.

O Grupo formulou recomendaçōes sobre os três temas, dirigidos aos Governos, e outras ainda objetivando futura ação internacional.

O Projeto de Declaração relativa a princípios sociais e legais referentes à proteção e bem-estar de crianças, com especial referência ao favorecimento de colocação e adoção em nível nacional e internacional foi aprovado aos 16.12.1981.

Contou com a participação ativa de cerca de 40 Países, desde a Argentina até a Zâmbia.

O Brasil brilhou... pela ausência total.

O segundo foi o Encontro Internacional de Estudos sobre Problemas do Direito do Menor à Família: adoçāo, convivência ("affidamento"), afiliação, que se desenvolveu em Sassari, de 10-11 de dezembro de 1979, e prosseguiu com sucessivas Mesas-redondas a 15.03.1980 e a 15-16.12.1980. 
Foi organizado por ocasião do Ano Internacional da Criança pelo Instituto Jurídico da Universidade de Sassari.

Dele resultou a publicação, pela Società Sassarese per le Scienze Giuridiche, do substancioso II Diritto del Minore alla Famiglia, aos cuidados do Prof. SANDRO SCHIPANI, reunindo as principais colaboraçōes de mais de 60 personalidades.

Suas 557 páginas estão divididas em duas partes.

A primeira reúne colaborações relativas a "O menor e as instituições", "O menor e a família" e "Perspectivas de Direito Comparado", de especialistas alemães, poloneses, espanhóis, colombianos, salvadorenhos, algerianos, encerrando com um compendioso estudo de ANGELO BERETTA sobre a "Adoção como experiência humana. Considerações psicológicas sobre os trabalhos do congresso".

O Prof. JOÃO BAPTISTA VILLELA, da Universidade Federal de Minas Gerais, Belo Horizonte, contribuiu com um estudo informativo e crítico, em italiano, sobre a adoção no direito brasileiro, em que a analisa no direito précodificado, a reforma realizada pelo Código Civil, a decorrente da Lei n⿳ 3133 , de 08.05.1957, outra, da Lei no 4655, de 02.06.1965, que introduziu a legitimação adotiva, por sua vez revogado este diploma pelo Código de Menores de 1979, substituindo-a pela adoção plena. Qualifica de adoção "à brasileira" o registro como próprio do filho alheio: "típica reação contra as exigências, as cautelas e os riscos da adoção".

A segunda parte, Documentos, reúne um projeto de lei sobre a reforma das intervençōes em matéria de assistência social, um programa de pesquisa sobre Problemas do direito do menor à família, dirigido pelo Prof. SANDRO SCHIPANI e um projeto de lei relativo à adoção e guarda de menores, aprovado pelo Senado italiano em data de 30.07.1982.

Existe em Roma um Instituto Jurídico do Espetáculo e da Informação, o que dá bem a medida da importância que à matéria é atribuída na península.

E um dos proeminentes membros dessa instituição, o conhecido especialista Prof. AUGUSTO FRAGOLAZ publicou, no ano passado, "Elementi di Diritto della comunicazione Sociale" - Contenuto.

A obra obteve imediato e merecido sucesso, não só por versar em profundidade tema dos mais atuais e importantes, como ainda pela peculiaridade do seu estilo escorreito e despretensioso, despido, pelo menos à primeira vista, de citações doutrinárias que tão freqüentemente tornam pesada a leitura de obras dessa natureza. 
Mas o segredo dessa exposição despojada, apesar da sua profundidade, decobre-se às págs. 226 até 355, que reúne uma grande cópia de citações da mais variada origem, sugerindo leituras complementares de obras não jurídicas mas que têm ou podem ter relação com os temas e problemas jurídicos tratados no volume.

Suas 400 páginas, editadas pela GEA, Via di Villa Patrizi 10, 00161 Roma, são divididas em quatro títulos: Premissas fundamentais, Proteção e Providências, Sacrifícios e Primeiras exigências de reforma.

Começa fazendo ver que existe uma comunicação social de direito público no sentido de mensagens não somente de proveniência pública, mas de natureza jurídica dirigidas a uma pluralidade de pessoas para informá-las, advertí-las, convidá-las etc., e passa ao estudo da comunicação social como instrumento de justiça pela publicação das sentenças de condenação pelos jornais, como contribuição à reparação do dano e como fato reintegrativo nos casos de uso indevido de nome, como sanção paradisciplinar, quando tenham sido realizados atos de concorrência desleal com dolo ou culpa.

Passando ao âmbito internacional examina os direitos do homem e a comunicação social nos principais documentos modernos: Carta das Nações Unidas, Declaração Universal dos Direitos do Homem, Convenção Européia para a Salvaguarda dos direitos do Homem e das Liberdades Fundamentais, Pactos de Nova Iorque, Ata final da Conferência de Helsinki, Convenção para a repressão da circulação e o tráfego das publicaçõs obcenas, a Convenção para a proteção das pessoas com relação ao tratamento automatizado de dados de caráter pessoal.

Traça um apanhado sintético da proteção das obras intelectuais, dos seus autores e usuários e mostra existirem outros conteúdos protegidos: firmas, siglas e insígnias comerciais e sinais distintivos, emblemas e denominações, símbolos de partido etc.

Capítulos sucessivos são dedicados à proteção da personalidade individual e da saúde, da personalidade do Estado, da vida política, da administração da justiça e dos públicos sentimentos: religioso, repeito pelos defuntos, fé pública e sensibilidade pública, obcenidade e indecência:

"Existem sentidos públicos em decadência, como o amor à pátria; mas outros sobrevêm, como o amor e o respeito à natureza e ao ambiente, a solidariedade com os povos subdesenvolvidos, a compreensão pelos marginalizados e pelos desprotegidos, enquanto que para alguns que ainda resistem, os contornos vão esvaecendo.

Destes últimos em particular formam argumento de disputas os do pudor $\mathrm{e}$ da decência por meio de processos evolutivos que podem mesmo não ser 
aprovados, mas dos quais não obstante o mundo jurídico - na sua variedade e complexidade - deve tomar conhecimento se não quiser permanecer cortado fora da realidade social.

Por outro lado não é certo que os poderes públicos sejam obrigados a agir em termos exclusivos de repressão, sendo talvez mais indicados os pedagógicos, persuasivos ou promocionais".

Não podia uma obra dessa natureza, pela modernidade de seu conteúdo, pela facilidade de exposição em temas muitas vezes candentes, que ameniza um estudo objetivo de problemas cruciantes, e pelo tato com que conduz uma grande quantidade de elementos informativos, alcançar merecido sucesso.

Prossegue assim o docente da Universidade Internacional da Arte de Florença, Diretor da "Rassegna di diritto cinematografico teatrale e dela radiotelevisone" e Presidente do Instituto Giurídico dello Spettacolo e dell'Informazione na sua faina de publicista, tendo já publicado: La ciematografia nella giurisprudenza, La radiotelevisione nella giurisprudenza e La legislazione italiana nella Cinematrografia, além de muitos ensaios e monografias diversas. 